DOI: $10.15290 /$ bsl.2021.18.02

\author{
Katarzyna Szalewska \\ Wydział Filologiczny \\ Uniwersytetu Gdańskiego \\ e-mail: k.szalewska@ug.edu.pl \\ ORCID: 0000-0003-2121-9864
}

\title{
Miron Białoszewski jako miejski rytmoanalityk. O roli spojrzenia w Chamowie
}

\begin{abstract}
Widok wydał mi się na pół nudny. Pośrodku między dziesięciopiętrowcami widać dalszy ukośny bieg Saskiej i przecięcia z jakąś, czasem autobus. Dalej domki, garaże, dwa łyski Wisły, bardzo skąpe, dalekie drzewa i na końcu trzy kominy z dymami - elektrownia na Siekierkach. Jak zamek. Po lewej stronie od lewego wieżowca widać pole Gocławka, szybowcowe. I na końcu kilka jedenastopiętrowców i kościół. Na prawo Czerniaków i nad Czerniakowem Mokotów. Idzie daleko, wysoko, jednym rzędem ${ }^{1}$
\end{abstract}

- pisze Białoszewski na jednej z pierwszych stron Chamowa. Ten tworzony od czerwca 1975 do maja 1976 roku dziennik stanowi jeden z podstawowych tekstów dla interpretatorów upatrujących w autorze Pamiętnika z powstania warszawskiego kronikarza życia w miejskim blokowisku. Jak wiadomo, zapiski stanowią świadectwo przestrzennej zmiany, jaka dokonuje się w biografii pisarza, który przeprowadza się do mieszkania w bloku przy ulicy Lizbońskiej w Warszawie. Można widzieć więc w Chamowie próbę werbalizacji specyficznej sytuacji egzystencjalnej Białoszewskiego - procesu zmiany adresu, która staje się też swoistą życiową cezurą ${ }^{2}$, zgodnie z przekonaniem,

\footnotetext{
1 M. Białoszewski, Chamowo, Warszawa 2009, s. 7. Kolejne cytaty lokalizuję w tekście głównym, oznaczając je skrótem $\mathrm{CH}$.

2 O silnym związku pomiędzy biografią a przestrzenią w pisarstwie Białoszewskiego wspomina w ten sposób Agnieszka Karpowicz: „Twórczość Mirona Białoszewskiego jest szczególnym przypadkiem geo-biograficzności literackiej między innymi ze względu na ścisły i nie-
} 
że "fazy uwzględnione w opowieściach biograficznych mają odniesienia przestrzenne, i to każda faza inne, sobie tylko właściwe, stąd potrzeba ich wyróżnienia i uporządkowania" ${ }^{3}$. To uporządkowanie stara się narzucić swojemu doświadczeniu sam Białoszewski, notując w dzienniku codzienne starania o wyobraźniowe i językowe oswojenie „miejsko-wiejskiej labilności nowego adresu" 4 .

Chamowo jest jednak nie tylko rejestracją „zasiedleńczych" działań podejmowanych przez pisarza i jego sąsiadów w przestrzeni gierkowskiego blokowiska ${ }^{5}$, nie tylko opisem spacjalnych aktywności charakterystycznych dla „mrówkowca”, ale również studium poświęconym spojrzeniu jako praktyce - kulturowej, przestrzennej, fenomenologicznej. Przywołany na początku tekstu cytat, pochodzący z jednej z pierwszych stron książki, buduje lejtmotyw, który powraca na kolejnych kartach dziennika - scenę patrzenia Białoszewskiego przez okna mieszkania przy Lizbońskiej ${ }^{6}$. Takich ujęć znajdziemy

rozerwalny związek poetyki przestrzennej tego autora z geograficzną, konkretną, miejską przestrzenią biograficzną, jej specyfiką topograficzną i historyczną, widoczny zwłaszcza $\mathrm{w}$ formach prozatorskich tego pisarza. Nie chodzi tu przecież jedynie o różne formy literackiego zapisu doświadczenia geobiograficznego, lecz o samoświadome czynienie z geobiograficznego doświadczenia i zakorzenienia materiału literackiego $\mathrm{w}$ taki sposób, że jest on uniwersalizowany, a tożsamość biograficzna nierozerwalnie splata się z tożsamością fragmentów miejskiej przestrzeni. Są to wręcz, czego dowodzą zwłaszcza zapiski z Chamowa, przestrzenie tożsame: doświadczenie topograficzne pozwala wyrażać treści biograficzne i egzystencjalne, a doświadczenie biograficzne jest wyrażane dzięki opowiedzeniu historii miejsca albo przekazaniu jej w krótkim montażu przestrzennym lub metaforze" [A. Karpowicz, Rytm prozy - rytm życia. Miron Białoszewski "ciało w ciało" z miastem, w: Przestrzenie geo(bio)graficzne w literaturze, red. E. Konończuk, E. Sidoruk, Białystok 2015, s. 297].

3 M. Czermińska, Przestrzenne odniesienia czasowych faz biografii, w: Przestrzenie geo(bio)graficzne $w$ literaturze, s. 13.

4 Chamowo - zrozumieć blokowisko, http://topo-grafie.uw.edu.pl/miron/chamowo/blokmirona / chamowo-zrozumiec-blokowisko/ [dostęp 16.01.2021].

5 „Miron Białoszewski przeprowadził się na ulicę Lizbońską 2 w 1975 roku, w samym środku dekady Gierkowskiej, dekady naznaczonej oddawaniem setek tysięcy mieszkań w wielkopłytowych, prefabrykowanych osiedlach $w$ całej Polsce. Osiedla powstawały zazwyczaj na peryferiach miast, na «stepach» - jak napisze autor dziejącego się na osiedlu Chamowa" [http:// topo-grafie.uw.edu.pl/miron/chamowo/blok-mirona/chamowo-zrozumiec-blokowisko/, dostęp 16.01.2021].

6 Joanna Grądziel-Wójcik stwierdza „Powtarzalna sytuacja wyglądania przez okno staje się modelowa dla «życiopisania» Białoszewskiego, stanowi egzystencjalną metaforę spotkania poety ze światem, «sprawdzania sobą» rzeczywistości: okno jest łącznikiem i granicą jednocześnie, autobiograficzną i zarazem estetyzującą ramą istnienia. Widok z niego staje się metaforycznym modelem percepcji i egzystencji, uruchamia podział na zewnętrzne i wewnętrzne i wskazuje na stopień zdystansowania podmiotu wobec świata” [J. Grądziel-Wójcik, "Święte życie" na Lizbońskiej. Architektura i sacrum w poezji Mirona Białoszewskiego, „Poznańskie Spotkania Językoznawcze" 2015, nr 30, s. 52]. 
w Chamowie bardzo wiele, konstruują one też kompozycję klamrową, jako że dziennik kończy ponowny zapis doświadczeń patrzącego, który dokonał już trudu oswojenia miejsca.

Białoszewski zapisuje doświadczenie spoglądania przez okno w całym bogactwie praktyk patrzenia, jakie uprawia (np. wspomagając wzrok lornetką czy odbywając wizyty na korytarzu na szczycie bloku jako szczególnej galerii widokowej). Wielokrotnie - nie tylko w Chamowie - tematyzuje sytuację patrzenia na miasto, także z wysokości, co pozwala widzieć w podmiocie jego twórczości nawigatora "ukrytego w bocianim gnieździe blokowego masztu" ${ }^{\prime \prime}$, latarnika nadającego sygnał ze swojej wieży-mrówkowca czy też - szczególnie w kontekście omawianego dziennika - kartografa ${ }^{8}$ nanoszącego na mapę własnej biografii kolejne, nieznane dotąd punkty, eksplorującego - z perspektywy wertykalnej, ale też horyzontalnej, jako przechodzień, „egzotyczne” dla przybysza ze Śródmieścia zaułki i uliczki.

Po odleżeniach, odkąpaniu się, z jagodami udałem się do tego miasta za wodami, które widać ode mnie w górze, w marszałkowski przełom Trasy jak między wielkie skały. Tu wysiadłem. Znalazłem się od razu po wyjściu ze schodków w tłoku południowego miasta. Egzotycznego [CH, s. 89-90].

Właśnie w ten sposób Białoszewski podejmuje trud zagospodarowania nieznanej przestrzeni własnego miasta. Po przeprowadzce do nowego miejsca zadomawia je poprzez praktyki trojakiego rodzaju: językowe, czego wyrazem sam dziennik, przestrzenne i praktyki spojrzenia. Te dwie ostatnie są wobec siebie komplementarne, analogicznie do współdziałania "mapy” i "trasy", o którym pisze Michel de Certeau:

W szczegółowej analizie opisu nowojorskich mieszkań, dokonanego przez lokatorów, C. Linde i W. Labov rozróżniają dwa typy: pierwszy nazywany „mapą" (map), drugi „trasą" (tour). [...]. Innymi słowy, opis oscyluje pomiędzy alternatywnymi pojęciami: albo widzieć (jest to poznanie pewnego porządku miejsc), albo iść (są to czynności tworzące przestrzeń). Albo ukaże on pewien obraz („tutaj znajduje się"), albo uporządkuje przemieszczenia („wchodzisz", „przechodzisz", „skręcasz") $)^{9}$.

W wypadku werbalizacji doświadczenia miasta $\mathrm{w}$ prozie autora Chamowa te dwa parametry - mapa i trasa, obraz i przemieszczenie, chodzenie

\footnotetext{
7 M. Jochemczyk, Egzotyka Chamowa. Metafory przestrzenne Mirona Białoszewskiego, w: Geografia i metafora, red. E. Konończuk, E. Nofikow, E. Sidoruk, Białystok 2014, s. 151.

8 Tamże.

9 M. de Certeau, Wynaleźć codzienność. Sztuki działania, przeł. K. Thiel-Jańczuk, Kraków 2008, s. 119 .
} 
i spojrzenie - są trudne do oddzielenia. Spojrzenie z góry zyskuje dopełnienie (czasem potwierdzenie, czasem korektę) w horyzontalnej perspektywie przechodnia („,udałem się do tego miasta za wodami, które widać ode mnie w górze"). Co więcej, zanegowaniu ulegają u Białoszewskiego również granice między tym, co widziane, a tym, co wyobrażone. Przestrzeń Chamowa, by zostać oswojona, musi najpierw przejść przez oko i język pisarza, który ją "opowiada”, tym samym kreując na własny użytek i przepuszczając przez filtr estetyzujący i egzotyzujący krajobraz blokowiska. To pod wpływem tego filtru, tego specyficznego spojrzenia podmiotu elektrownia zmienia się w zamek: „Wiem, dlaczego elektrownia na Siekierkach kojarzy się z zamkiem. Jest wielka, graniasta. Ma wysoko długie rzędy okien, oświetlonych. I te oświetlenia falują od odległości na ciepłym powietrzu. Mrugają" [CH, s. 121], a szkolne boisko - w "kaprawe lustro z czasów Temistoklesa” [CH, s. 309] ${ }^{10}$. Jak zauważa przywoływany już de Certeau:

Wszechogarniające oko, powstałe $\mathrm{w}$ wyobraźni dawnych malarzy, przetrwało w naszych dziełach. [...]. Czy owa rozpościerająca się przed nami, nieogarniona tekstura jest może czymś innym niż tylko przedstawieniem albo optycznym artefaktem? Jest ona odpowiednikiem kopii - czyli projekcji będącej rodzajem oddalenia - jaką sporządza planista, urbanista czy kartograf. Miasto-panorama jest "teoretycznym" (to znaczy, wzrokowym) symulakrem, wreszcie obrazem, którego warunkiem zaistnienia jest zapomnienie lub nieznajomość praktyk ${ }^{11}$.

Jakkolwiek w wypadku Białoszewskiego trudno zgodzić się z utożsamieniem upodobania do miejskiej panoramy z nieznajomością praktyk przestrzennych, $\mathrm{w}$ tym praktyk chodzenia, to zasadne wydaje się skojarzenie gestu spojrzenia na miasto $\mathrm{w}$ perspektywie wertykalnej z projekcją i kartografią. W Chamowie znajdziemy liczne opisy miejskich spacerów, doświadczania przestrzeni w sposób wielozmysłowy, spotkań z innymi przechodniami (a także świadectw percypowania Warszawy z perspektywy użytkownika

\footnotetext{
${ }^{10}$ Jak pisze Mariusz Jochemczyk, egzotyzacja, jakiej dokonuje Białoszewski, sprawia, że „Mieszkańcy «okolicy Lizbońskiej» to nie tylko pospolite ofiary małej socjalistycznej stabilizacji, ale też drapieżne Chimery z Notre Dame [CH, s. 71], Szekspirowscy królowie porzucający swe szaty [CH, s. 382], mityczne Nubijki o krągłych kształtach [CH, s. 138], bohaterowie dziejowi żyjący dyskretnie za blokową ścianą: jak - dajmy na to - wścibska sąsiadka, metamorfozująca się nieoczekiwanie w cesarzową bizantyjską Teodorę [CH, s. 230]. Zaokienny widok przybiera formę tradycyjnego malarskiego tryptyku [CH, s. 102] lub Blake'owskiej solarnej fantasmagorii [CH, s. 123], obskurne boisko szkolne pobliskiego technikum odbija promienie wschodzącego słońca niczym «kaprawe lustro z czasów Temistoklesa» [CH, s. 309]" [M. Jochemczyk, Egzotyka Chamowa, s. 168-169].

11 M. de Certeau, Wynaleźć codzienność, s. 94.
} 
komunikacji publicznej ${ }^{12}$ ) - Białoszewski jest przecież w całej swojej twórczości mistrzem werbalizacji przemieszczenia, ruchu, trasy. Z drugiej strony jako przynajmniej równoważne, jeśli nie dominujące, uznać należy te fragmenty dziennika, które poświęcone zostały mapie, obrazowi, czyli spojrzeniu właśnie. I w tym wymiarze odczytania Chamowa zasadna wydaje się analogia stworzona przez de Certeau między miejską panoramą a projekcją i kartografią.

Była już mowa o tym, że Białoszewski oswaja doświadczenie przeprowadzki, patrząc $w$ okno swojego mieszkania przy Lizbońskiej i w geście tym stając się niby-kartografem, który sporządza mapę nowej, nieznanej przestrzeni. Praca zagospodarowania osiedla odbywa się poprzez zapełnianie białych plam, poszukiwanie punktów orientacyjnych, tworzenie swoistej siatki kartograficznej, czynienie z przestrzeni blokowiska miejsca zamieszkania dzięki nazywaniu, ale też projekcji, drugiemu ze skojarzeń de Certeau. Osiedle staje się ekranem, na który pisarz rzutuje swoje lęki, marzenia, fantazje, a nawet odczucia somatyczne. Co więcej, Białoszewski "przepuszcza” zaokienne widoki przez filtr własnej erudycji kulturowej:

To dziewiąte piętro. Ze schodów widać całą Warszawę i Pragę. Kamieniołomy miasta. Nad tym wszystkim półzanurzone w chmurach, wiszące słońce. Czerwone. Kawałki mostów, pociągi, wieżowce nad wieżowcami, niezwykłe przeklockowywania szarości, i pchające się na siebie, i takie między zieleniami. Kiedy szliśmy do autobusu przez mostek, zobaczyłem, że Saska Kępa jest jednak tuż i że z mostku widać Grochów, parawanowo, ładnie, a spodem szara Trasa jak mostek. Mostek wygięty - niby nad Canale Grande [CH, s. 7].

Powyższy fragment przynosi skojarzenie niepoznanej jeszcze i nie-swojej przestrzeni (cytat pochodzi z jednej z pierwszych stron dziennika) z tą oswojoną kulturowo, bo przecież nie biograficznie, i tą zmitologizowaną, narosłą narracjami, w których "zadomowiony" jest podmiot.

Określenia „przeklockowywania szarości” czy „parawanowo” (a także widziana z okna elektrownia, która pod wpływem spojrzenia Białoszewskiego zmienia się w zamek i która jest "graniasta") oraz odniesienia do kolorystyki widoku świadczą o procesie estetyzowania przestrzeni blokowiska i jednocześnie przywodzą na myśl architektoniczną wyobraźnię malarską takich twórców, jak choćby Giorgio de Chirico, geometryzujących miasto, widzących w budynkach szczególną estetykę bryły.

12 Na ten temat zob. np. A. Karpowicz, "Autobusiarnia” Mirona Białoszewskiego. Komunikacja miejska jako akt komunikacji, „Kultura Współczesna” 2012, nr 2. 
W Chamowie „[e]lementy krajobrazu [...] wchodzą w grę geometrycznych regularności, odbijając abstrakcyjne formy blokowiska i zarazem mierząc się z funkcjonalistyczną ideą osiedla" ${ }^{13}$, Białoszewski w wielu miejscach buduje swój opis z określeń wskazujących na geometryczne relacje między widzianymi obiektami i ich zbieżność z bryłami. Równocześnie ta architektoniczno-geometryczna wyobraźnia podmiotu patrzącego w Chamowie dialoguje z fantazmatyką organiczną, przekształcającą beton $\mathrm{w}$ materię ożywioną (w tych fragmentach, bardzo licznych, w których pisarz staje się obserwatorem przyrody ${ }^{14}$ ), oraz $\mathrm{z}$ wyobrażeniami wyrosłymi $\mathrm{z}$ obcowania ze sztuką europejską. W każdym $\mathrm{z}$ tych wypadków praktyki patrzenia, jakie uprawia Białoszewski, odnieść można do „tradycji malarstwa, zarówno do metafory «obrazu jako okna», jak i - będącego fundamentem malarstwa pejzażowego - procesu kadrowania"15. Praktyki te uzmysławiają "funkcję parergonu, jako warunkującego zaistnienie dzieła sztuki - w tym wymiarze najistotniejszym aspektem jest «matrycowanie» spojrzenia, które dokonuje się poprzez ramę"16. Jak zauważa Agata Stronciwilk:

Metafora obrazu jako okna pojawia się $\mathrm{w}$ traktacie Leona Battisty Albertiego, który pisze: „Obraz więc będzie pewnym przecięciem piramidy widzenia, utworzonym na dowolnej powierzchni za pomocą linii i kolorów przy stałym oddaleniu i przy ustalonym promieniu centrycznym oraz świetle". Stoichita, przytaczając definicję obrazu, wskazuje na jego podwójne rozumienie - tableau oznacza bowiem zarówno „dzieło malarskie na drewnianej, miedzianej płycie bądź płótnie", jak $\mathrm{i}$ „w architekturze oznacza otwory drzwiowe, okna i otwory okienne, otwory w murze pozwalające na doświetlenie wnętrza bądź wejście do po$\mathrm{koju}^{\prime \prime 1}$.

Ta podwójna rola okna (zarówno tego w mieszkaniu na Lizbońskiej, jak i na korytarzu widokowym na ostatnim piętrze bloku) zostaje wyzyskana w Chamowie. Okno stanowi tu jednocześnie obraz - w wielorakim tego słowa znaczeniu - rozumiany jako projekcja ,ja”", ale też w kontekście malarskim,

13 http://topo-grafie.uw.edu.pl/miron/chamowo/blok-mirona/chamowo-zrozumiec-bloko wisko/ [dostęp 16.01.2021].

$14 \mathrm{Z}$ braku miejsca nie uwzględniam tu ważnego aspektu Chamowa, jakim jest obserwacja miejskiej przyrody. Więcej na ten temat zob. A. Karpowicz, Dzika natura Mirona Białoszewskiego, „Teksty Drugie" 2018, nr 2; D. Korczyńska-Partyka, Urbanonatura - hybrydyczna przestrzeń miasta. Na przykładzie twórczości Mirona Białoszewskiego, „Teksty Drugie” 2018, nr 2.

15 A. Stronciwilk, Parergon. O granicach, ograniczeniach i tożsamości obrazu w twórczości Kamila Kuskowskiego, w: Pomiędzy tożsamościq a obrazem, red. M. Markiewicz, A. Stronciwilk, P. Ziegler, Katowice 2016, s. 203.

16 Tamże.

17 Tamże, s. 203-204. 
co wzmacniane jest przez plastyczność opisu i liczbę intersemiotycznych odwołań, które czyni Białoszewski, np.:

Podszedłem do okna w kuchni. Jacyś młodzi na dziewiątym czy dziesiątym piętrze gadali głośno do innych w moim mrówkowcu. Wychyliłem się, wychyliły się na lewo ręce, potem głowa, spojrzałem $\mathrm{w}$ deszcz na prawo, a tu ze ścian, z szarych wgłębień znów tu głowy, tu ręce. Chimery z Notre-Dame [CH, s. 70-71].

Framugi pełnią funkcję ramy niezbędnej dla skadrowania spojrzenia. Wspomniane "matrycowanie" dochodzi do głosu wielokrotnie, gdy czytamy w Chamowie opisy zaokiennego widoku:

Patrzyłem na dom naprzeciwko. Ukosem, więc z dwóch stron jedenaście kondygnacji z życiami. W różnych skrótach. Jak oglądanie sceny z wszystkich naraz miejsc. [...] Światła w wielu oknach. Ale za chwilę, jak doszedłem do widoku, to $\mathrm{w}$ iluś dachach i asfaltach jak w świecących lustrach, niżej, wyżej, dalej, stał, wisiał deszcz [CH, s. 15-16].

Chamowo poddane zostaje kadrowaniu, jakie wymuszają ograniczenia okna-ramy. To, co wewnątrz niej, przemienia się w sztukę - tutaj przyrównaną do obrazu filmowego. „Ukosem”, „Z dwóch stron”, „w różnych skrótach” codzienne życie mieszkańców osiedla zyskuje nowe znaczenia dzięki działaniu okna-parergonu. Banalna figura blokowiska zmienia się pod wpływem spojrzenia podmiotu w przestrzeń fascynującą niczym kino. Proces zagospodarowywania nowego miejsca wspierany jest więc w dzienniku przez trud "zobaczenia" i odpowiedniego skadrowania widzianego.

Wertykalna perspektywa, jaką przyjmuje wobec Warszawy Białoszewski w Chamowie, jest kontynuacją bogatej tradycji portretowania przestrzeni urbanistycznej. To właśnie widoki „z góry”, z dystansu stoją najczęściej u podstaw malarskich przedstawień miasta. Ale perspektywiczność spojrzenia przywodzi na myśl również bogatą tradycję literackich deskrypcji przestrzeni urbanistycznej. Siedzenie w kawiarni i spoglądanie zza jej okna czy wyglądanie na ulicę zza firan własnego mieszkania to jedno z podstawowych, mających najstarszą historię i najczęściej spotykanych w literaturze urbanistycznej ujęć pozwalających na zdefiniowanie sytuacji narracyjnej i wprowadzenie miejskiej zdarzeniowości. Narrator staje się obserwatorem rozgrywającego się za szybą spektaklu. Szkło gwarantuje kompromis między opozycyjnymi kategoriami wnętrza i zewnętrza, ,jj" i miasta, tłumu i pojedynczości, koniecznej do stworzenia korporalnego punktu widzenia, do osadzenia narracji w ciele, biografii i świadomości bohatera. Właśnie ten somatyczny wymiar spojrzenia 
uwidacznia się w Chamowie. Agnieszka Karpowicz łączy ten sposób widzenia miasta u Białoszewskiego z kategorią „ruchomego, psychofizjologicznego oka", a samo widzenie miasta określa jako somatyczne i uzależnione od pozycji obserwatora ${ }^{18}$.

Powiązanie ciała obserwatora z konstrukcją spojrzenia skutkuje licznymi fragmentami, w których Białoszewski werbalizuje subiektywizm widoku, uzależnionego każdorazowo od nastroju i samopoczucia podmiotu patrzącego. To on jest właściwym konstruktorem blokowiska - musi je „wytworzyć", opowiedzieć, ogarnąć okiem, by sukcesem zakończyć trud zamieszkiwania. Pracę, jaką podejmuje Białoszewski w dzienniku, uznać należy za wykonaną, o czym świadczyć może jeden z końcowych fragmentów Chamowa poświęcony sytuacji spoglądania przez okno:

Widok na Chamowo. Znany. Wiadome garaże, parkaniki. Te na początku wybrzydzane, a potem urządzające mi dodatkowe uliczki. Pawilon z tyloma sklepami. Pół roku temu pusty, tajemniczy. Pole za pawilonem przeorane, dalsze bloki, wloty, Wał Miedzeszyński z przelatującymi okienkami autobusów. Co tu dużo mówić, to wszystko swoiste, już. Rozszyfrowane po horyzont, bo i pola za Wisłą, drzewa, domki, i Siekierki z elektrownią, z kominami. Mam już tu wspomnienia, wspólne przeżycia z tymi zakamarkami, zmiany, świadkowanie. Już nie mogę się tego Chamowa wyprzeć. [...] Nazwa "Chamowo" na dobrą sprawę to tu nie tak znów pasuje. Malutko tego Chamowa, uporządkowane, zakończone, z polotami, z atrakcjami. Trasa, lotnisko, step, Wisła, dżungla, most, mostki, Saska Kępa. I to wszystko w kupie. Kto ma tyle naraz? [CH, s. 293-294]

Figura okna pojawia się w literaturze niezmiernie często. By przywołać tylko klasyczne ujęcia: Człowiek tłumu Edgara Allana Poe z bohaterem obserwującym uliczny teatr z kawiarni i Narożne okno E.T.A. Hoffmanna z wyłożoną tam „sztuką patrzenia” przez okno właśnie, polegającą na bacznej obserwacji przechodniów i reżyserowaniu ich zmyślonych biografii - to dwa archeteksty nowoczesnej literatury urbanistycznej (i to nie tylko, jeśli wziąć pod uwagę popularność tego ujęcia również w kulturze popularnej,

18 Jak formułuje to badaczka: „Rytm jest zaś czymś, co składa się z momentów widzenia i niewidzenia, przerw powstających przy przenoszeniu spojrzenia, przy zmianie pola widzenia, a więc także przy ruchu osoby patrzącej, jak na przykład podczas spaceru w parku Skaryszewskim. [...]. Dostajemy tu literacką ideę rytmu, odsyłającą jednak do fizycznych właściwości motoryki i związanej z nią fizjologiczności patrzenia. Czytając notatki Chamowa, a szczególnie te, które są zapisem widzenia miasta, nie sposób nie spostrzec, że narrator odwołuje się nieustannie do kategorii ruchomego, psychofizjologicznego oka, a przez to - widzenia cielesnego, ruchomego, sprawiającego, że to, co jest postrzegane, zależy po części od tego, w jakiej kondycji i pozycji znajduje się ciało obserwatora" [A. Karpowicz, Rytm prozy - rytm życia, s. 291-292]. 
a w Narożnym oknie dostrzec źródło inspiracji dla takich filmów, jak Okno na podwórze Alfreda Hitchcocka). Kompozycja tekstów poświęconych miastu bardzo często oparta jest na ramie narracyjnej, która umożliwia organizację materiału i jednoczesne wskazanie na ich urbanistyczny, spacjalny rodowód.

Ewa Rewers wyszczególnia trzy sposoby ujmowania miejskiego spektaklu w sztuce: omówiony widok okienny, punkt widzenia przechodnia oraz „perspektywę pielgrzyma stojącego u bram miasta" ${ }^{19}$. Wskazując na znaczenie tej tradycji dla współczesnej wyobraźni miejskiej, pisze o Narożnym oknie E.T.A. Hoffmanna i opartym na podobnym koncepcie Oknie na ulice Franza Kafki:

Uwięzieni między wnętrzem i oknem, między samotnością i społecznością, które usiłują nad nimi zapanować zgodnie z rytmem przybliżania się i oddalania od miejskiego spektaklu docierającego niemal równocześnie do oczu (ślady) i do uszu (głosy) przez okno, starają się dostosować swoje wewnętrzne rytmy do rytmów miejskich, które są rytmami życia społecznego. [...] Oni [Hoffmann, Lefebvre, Kafka - dop. K.S.] próbują te rytmy opowiedzieć, mimo ograniczeń języka, nieudolnie usiłującego odwzorować wszystko, co przynosi ze sobą ruch. Wszystkich ich łączył podobny rodzaj zainteresowania miejskim spektaklem, widowiskiem „widzianym z okna”. Pomimo różnic zatem, wszyscy zaakceptowali kartezjańską perspektywę, która dała początek nowoczesnemu miastu: świat miejski konstytuuje się tu $\mathrm{w}$ świadomości samotnego podmiotu jako rzeczywistość podmiotowa. Stara metafora pokoju, z którego okna oglądamy świat, jest przecież kontynuacją jednej z podstawowych dychotomii metafizyki: świata wewnętrznego oddzielonego od świata zewnętrznego, przedmiotu od poznającego go, zdystansowanego podmiotu ${ }^{20}$.

„Kończy się już popołudnie. Pełno chodzi i stoi dzieci, na różnych asfaltach. O ósmej rano schodzą się z teczkami po tych różnych asfaltach w gwiazdę do szkoły, słychać dzwonki" [CH, s. 138] - notuje Białoszewski, którego obserwacje można przyrównać do wsłuchiwania się w rytm miasta zgodnie z praktyką opisaną przez Henri Lefebvre'a. Chamowo ma swój własny rytm wyznaczany choćby, jak w powyższym fragmencie, przez szkolne dzwonki, a geometrycznie wyobrażony przez pisarza $w$ figurze gwiazdy. Blisko stąd do rytmoanalizy jako metody spojrzenia na miasto proponowanej przez autora Produkcji przestrzeni, dla którego modelową sytuacją było, podobnie jak dla Kafki, Poego czy Hoffmana, spoglądanie na miasto przez okno, umożliwiające percepcję bez uczestnictwa. Jak pisze Lefebvre:

\footnotetext{
19 E. Rewers, Post-polis. Wstęp do filozofii ponowoczesnego miasta, Kraków 2005, s. 63.

20 Tamże.
} 
Żeby pochwycić wzrokiem przepływające obiekty, [...] trzeba usytuować się jednocześnie wewnątrz i na zewnątrz. Balkon idealnie spełnia tę funkcję w swojej relacji do ulicy. Dzięki wytwarzaniu perspektywy, w jaką ujmuje się ulicę, mamy cudowną koncepcję balkonu i tarasu, z którego można dominować nad ulicą i przechodniami ${ }^{21}$.

Białoszewski, usytuowany jednocześnie wewnątrz i na zewnątrz opisywanej przestrzeni, śledzi miejski rytm o różnych porach. Kontrastując specyfikę upływu czasu na blokowisku i „w centrum” Warszawy, pisze:

W nocy prawie nikt nie chodzi moimi uliczkami. I znów tęsknię za widokiem ze starego balkonu. Zawsze coś było. Dziesięciopiętrowce naprzeciwko zamknięte, niewidoczne, pozasłaniane, nabite bez wdzięku, klitkowato-tajemnicze. Odwrotność Alhambry [CH, s. 56].

"Nabite" bez dźwięku bloki wpływają na inny rytm osiedla niż ten doświadczany w Śródmieściu. Dla Lefebvre'a rytm to repetycja o określonej częstotliwości, właściwość przeżywania czasoprzestrzeni. Jak sam definiuje, ,[w]szędzie tam, gdzie zachodzi interakcja między miejscem, czasem a wydatkiem energii, istnieje rytm. Rytm niesie więc ze sobą zróżnicowany czas, wartościowy czas trwania. To samo można powiedzieć o powtórzeniach, pęknięciach i wznowieniach" 22. Lefebvre'a w projekcie rytmoanalizy, czyli badania rytmu codziennego życia, interesują przede wszystkim momenty, a więc jednostki czasowo-przestrzenne, w których dzięki zawieszeniu, przerwie, anomalii możliwa staje się obserwacja rytmu. Rytm jest doznawany zmysłowo, a cel rytmoanalizy to uzyskanie dostępu do chwili, w której się on objawia, zwanej przez Lefebvre'a obecnością i teraźniejszością jednocześnie, gdyż takie konotacje niesie ze sobą translatorsko trudne słowo presence.

Na dziewiątym naprzeciwko idzie film. Szybkie zmiany postaci i gęby na planie. Pstryk - chłop. Pstryk - baba. Widzę niecałość, bo rama okna odkrawa resztę ekranu. Łyskają kawałkami siebie w okienkach łazienek czy kuchenek. [...] $\mathrm{Na}$ Afrykańskiej w iluś oknach też życie. Zamazane, bo daleko [CH, s. 71].

We fragmencie tym uwidacznia się i estetyzująca, przestrzenio-twórcza rola ramy, i powiązanie okna $\mathrm{z}$ malarstwem, a wreszcie - uzależnienie percepcji rytmu miasta od pozycji podmiotu. Językowe opracowanie tego i wielu innych wpisów w Chamowie widzieć więc można jako próbę werbalizacji rytmu osiedla. O tych właściwościach twórczości Białoszewskiego zresztą

${ }^{21}$ H. Lefebvre, Seen from the Window, w: tegoż, Rhythmanalysis. Space, Time and Everyday Life, trans. S. Elden, G. Moore, introd. S. Elden, London-New York 2004, s. $27-28$ [przeł. - K.S.].

${ }^{22}$ H. Lefebvre, The Critic of the Thing, w: tegoż, Rhythmanalysis, s. 15. 
pisano wiele ${ }^{23}$, wskazując na językowe, anakolutyczne dostrajanie się przede wszystkim jego poezji do pulsu miasta. Autora Chamowa uznać bowiem trzeba za jednego z mistrzów synchronizacji z pulsującym żywiołem zjawisk atakujących wszystkie zmysły i wprowadzających rozmaite, często wzajemnie sprzeczne, wymiary temporalne. Jego twórczość - niczym chronometr odmierza miejskie szumy i ciągi, puls Warszawy, bloku czy przedmieścia ${ }^{24}$.

Stworzona przez Lefebvre'a koncepcja już w swoim założeniu miała służyć (i służy nadal w obrębie wielu kierunków współczesnych kulturowych badań przestrzeni) do analizy miasta jako największego laboratorium codziennych praktyk spacjalnych, ekonomicznych i kulturowych oraz jako miejsca interakcji pomiędzy rytmem wielu podmiotów a pulsem stworzonego przez nie urbanistycznego organizmu. Regularne przypływy i odpływy miejskiego tłumu, szerokie spektrum codziennych, powtarzalnych praktyk przestrzennych, dźwięki i zapachy miasta - wszystko to stanowi podkład życia $\mathrm{w}$ metropolii, ofiarowuje poczucie bycia w danym czasie i miejscu. Rutynowe działania podejmowane przez mieszkańców miast, trasy i odgłosy dzieci idących do szkół, fale dojazdów do pracy i powrotów, fazy ruchu w sklepach, tłumy imprezowiczów w weekendowe wieczory, trajektorie przejazdów studentów, tempo życia niepracujących, otwarcia i zamknięcia centrów handlowych, przepływy dostaw pocztowych, rozkład jazdy transportu publicznego, godziny zapalania i gaszenia latarń - to liczne, ale przecież tylko niektóre czynniki budujące skomplikowany rytm miasta. Świadomy jest tego także Białoszewski obserwujący zdarzeniowość miejskiego osiedla:

Wszedłem w trans wyglądania oknem. Znalazłem punkt środkowy. Bardzo niepozorny. Narożnik małego murku z rozchodzącymi się ścieżkami asfaltowymi. Długo wyglądałem oknem i patrzyłem na ten murek, czekając, aż ktoś będzie szedł. Mijało pół godziny, godzina, półtorej, nikt nie szedł. Zdawało mi się, że zetknięcie się idącego człowieka z nieruchomym narożnikiem murku to będzie wydarzenie $[\ldots]^{25}$.

23 Zob. np. wieloautorską monografię Tętno pod tynkiem. Warszawa Mirona Białoszewskiego, red. A. Karpowicz i in., Warszawa 2013.

24 „Białoszewski z uporem i na różne sposoby stara się nas przekonać, że ludzkie ciało i jego reakcja na miejskie rytmy muszą być zawsze spóźnione w stosunku do wyprzedzającej je «rytmiki» miasta. A także, że nie mamy tu do czynienia z przypadkową ułomnością człowieka, lecz $\mathrm{z}$ ujawnieniem niedostosowania aparatu językowego obsługującego myślenie do rytmów ciała i miasta. [...] językowe uobecnianie miasta [...] pociąga za sobą lingwistycznie niewyjaśnialne «psucie» języka. Język, w którym uobecniamy miasto, nie może zachować przypisanego mu przez reguły kodu rytmu, ponieważ rytm miasta nie jest tożsamy z rytmem języka. Uobecniając miasto wypadamy zatem z rytmu i «coś psujemy w języku». Lingwistyka potrafi odpowiedzieć na pytanie «co?», eksperyment pisarski na pytanie «dlaczego?»" [E. Rewers, Post-polis, s. 58].

25 M. Białoszewski, Tajny dziennik, Kraków 2012, s. 640. 
Lefebvre'owski projekt rytmoanalizy miejskiej przynosi szczegółowe klasyfikacje związków między rytmami, które, jeśli ulegają zaburzeniu i są ze sobą $\mathrm{w}$ konflikcie, prowadzą do doświadczenia arytmii, współdziałają $\mathrm{w}$ tym samym czasie $\mathrm{w}$ polirytmii, harmonijnie współbrzmiąc, tworzą eurytmię, wreszcie - układając się $\mathrm{w}$ miarowe, hierarchicznie uszeregowane powtórzenia i określone częstotliwości - oznaczają izorytmię ${ }^{26}$. Najważniejszy pozostaje jednak moment arytmii, która, podobnie jak ta kardiologiczna (cały czas jesteśmy bowiem $\mathrm{w}$ obrębie słownika Lefebvre'a uzgadniającego słownictwo medyczno-somatyczne z leksyką urbanistyczną), oznacza zaburzenie, dysharmonię. I tak jak sercowa dolegliwość kieruje uwagę chorego na własny organizm, tak dopiero zakłócenie funkcjonowania codziennego rytmu miejskiego uświadamia nam jego nieustającą obecność. Lefebvre tłumaczy działanie eurytmii jako stanu równowagi, a arytmii jako konfliktu w analogii do procesów żywego organizmu: krążenia, trawienia, oddychania.

Ta somatyczna paralela okazuje się bardzo trafna w kontekście Chamowa, którego autor boryka się z kardiologicznymi właśnie problemami. „W nocy zakłócenia oddechowe, o wiele za szybkie bicie serca. Stałem w oknie otwartym na mróz. Bałem się przeziębić, ale to dosyć pomagało. Bolało też. I to za mostkiem" [CH, s. 237] - pisze Białoszewski, a fragment ten udowadnia trafność kategorii „oka psychofizjologicznego”, widzenia uzależnionego od kondycji podmiotu patrzącego, doświadczania miasta, w którym niemożliwym staje się wyznaczenie granicy ciała i przestrzeni wokół, wnętrza i zewnętrza. Jednocześnie jednak, na co zwraca uwagę Lefebvre, dopiero pęknięcie $\mathrm{w}$ chronotopie, zafałszowanie rytmu może doprowadzić do odczucia presence i świadomej percepcji miejskiego szumu.

Białoszewski analizuje rytm osiedla - jego doświadczanie Chamowa ma wymiar multisensoryczny: akustyczny i wizualny. Pole deskrypcji, czy też fokalizacji, w dzienniku jest zawężone pozycyjnymi ograniczeniami podmiotu. Umiejscowienie wiąże się tu ściśle z „ucieleśnieniem” 27. Zawężenie pola

\footnotetext{
${ }^{26}$ Klasyfikację miejskich rytmów referuję za: H. Lefebvre, Conclusions (Résumé), w: tegoż, Rhythmanalysis, s. 67-68.

27 Utożsamienie to przejmuję od Magdaleny Rembowskiej-Płuciennik, która w ten sposób definiuje literacką fokalizację: „Biorąc pod uwagę elementy poetyki utworu, można wskazać markery przestrzennej lokalizacji narratora jako figury tekstowej, a są nimi ramy pola deskrypcji, ograniczenia pozycyjne i perceptualne atrybucje. [...] Fokalizacja tak pojęta oddaje charakter wieloźródłowych doznań sensualnych, płynnie przechodzących w odmienne zmysłowe modalności lub w doświadczenia synestezyjne, reprezentuje ich zmienne natężenie, nieustające oscylowanie między stanami aktywności i przytłumienia percepcji. Ten aspekt percepcji dominuje obecnie $\mathrm{w}$ interdyscyplinarnych studiach nad działaniem ludzkiego sensorium
} 
deskrypcji - Białoszewski widzi to, co zawiera się wewnątrz okiennej ramy - sprzyja teatralizacji przestrzeni, ale też pozwala na uznanie (na zasadzie synekdochy) tego wycinka blokowiska za pars pro toto dzielnicy, którą zagospodarowuje pisarz poprzez pracę spojrzenia. Okno jest jednocześnie łącznikiem między wnętrzem a zewnętrzem, prywatnością a życiem społecznym Chamowa i „narzędziem” ułatwiającym pracę zadomowienia nowej przestrzeni, zgodnie z ustaleniami Pierre'a Mayola, który pisze:

\begin{abstract}
Ze względu na czyniony z niej użytek dzielnica może być traktowana jako stopniowe prywatyzowanie przestrzeni publicznej. Jest to praktyczny mechanizm, który ma zapewnić ciągłość pomiędzy tym, co najbardziej intymne (prywatną przestrzenią mieszkania), a tym, co najbardziej nieznane (całym miastem, a nawet w szerszym znaczeniu - pozostałą częścią świata): istnieje relacja pomiędzy pojmowaniem mieszkania (jakąśs „wewnętrznością") i pojmowaniem przestrzeni miejskiej, do której jest ono przywiązane (jakąś "zewnętrznością"). Dzielnica jest pośrednim terminem dialektyki egzystencjalnej (na poziomie osobistym) i socjalnej (na poziomie grup użytkowników), pomiędzy wewnętrznością a zewnętrznością. I w owym napięciu pomiędzy dwoma terminami, [...] dokonuje się zawłaszczenie przestrzeni ${ }^{28}$.
\end{abstract}

Białoszewski notuje $\mathrm{w}$ dzienniku stopniowe meblowanie mieszkania na Lizbońskiej przyniesionymi przez przyjaciół przedmiotami - meblami, akcesoriami, ozdobami. To, co dzieje się we wnętrzu bloku, zyskuje prawie $\mathrm{w}$ każdym wpisie dopełnienie $\mathrm{w}$ deskrypcji aktu patrzenia przez okno - na dzielnicę, na sąsiednie budynki, na przechodniów. W ten sposób dokonuje się w Chamowie nie tylko artystyczny akt przetwarzania widzianego w wymyślone (poprzez projekcję, kadrowanie i teatralizację), intelektualny akt mapowania miasta (poprzez przyjęcie perspektywy wertykalnej i rytmoanalizę), ale również emocjonalny proces poszerzania udomowionej i traktowanej jako „swoja" przestrzeni - od własnego ciała przez wyróżnione miejsca mieszkania po „swoje" Chamowo.

oraz jego kulturotwórczym charakterem. Fokalizację zmysłową uznaję właśnie za jedną z najważniejszych literackich figur dynamiki i symultanicznej wielosensoryczności doświadczenia zmysłowego, która stanowi tekstowy wykładnik związku między embodiment a emplacement (ucieleśnieniem a umiejscowieniem)" [M. Rembowska-Płuciennik, W cudzej skórze. Fokalizacja zmysłowa a literackie reprezentacje doświadczeń sensualnych, w: Literackie reprezentacje doświadczenia, red. W. Bolecki, E. Nawrocka, Warszawa 2007, s. 60-62].

28 P. Mayol, Mieszkać, w: M. de Certeau, L. Giard, P. Mayol, Wynaleźć codzienność 2. Mieszkać, gotować, przeł. K. Thiel-Jańczuk, Kraków 2011, s. 7. 


\section{Bibliografia}

Białoszewski Miron (2009), Chamowo, Warszawa: Państwowy Instytut Wydawniczy.

Białoszewski Miron (2012), Tajny dziennik, Kraków: Wydawnictwo Znak.

Certeau Michel de (2008), Wynaleźć codzienność. Sztuki działania, przeł. K. Thiel-Jańczuk, Kraków: Wydawnictwo Uniwersytetu Jagiellońskiego.

Czermińska Małgorzata (2015), Przestrzenne odniesienia czasowych faz biografii, w: Przestrzenie geo(bio)graficzne w literaturze, red. E. Konończuk, E. Sidoruk, Białystok: Wydawnictwo Uniwersytetu w Białymstoku, s. 11-39.

Grądziel-Wójcik Joanna (2015), "Święte życie” na Lizbońskiej. Architektura $i$ sacrum w poezji Mirona Białoszewskiego, „Poznańskie Spotkania Językoznawcze”, nr 30, s. $45-62$.

Jochemczyk Mariusz (2014), Egzotyka Chamowa. Metafory przestrzenne Mirona Białoszewskiego, w: Geografia i metafora, red. E. Konończuk, E. Nofikow, E. Sidoruk, Białystok: Wydawnictwo Uniwersytetu w Białymstoku, s. 149-171.

Karpowicz Agnieszka (2012), „Autobusiarnia” Mirona Białoszewskiego. Komunikacja miejska jako akt komunikacji, „Kultura Współczesna”, nr 2, s. 61-73.

Karpowicz Agnieszka [red.] (2013), Tętno pod tynkiem. Warszawa Mirona Białoszewskiego, Warszawa: Lampa i Iskra Boża.

Karpowicz Agnieszka (2015), Rytm prozy - rytm życia. Miron Białoszewski "ciało w ciało" z miastem, w: Przestrzenie geo(bio)graficzne w literaturze, red. E. Konończuk, E. Sidoruk, Białystok: Wydawnictwo Uniwersytetu w Białymstoku, s. 287-303.

Karpowicz Agnieszka (2018), Dzika natura Mirona Białoszewskiego, „Teksty Drugie”, nr 2, s. 166-185.

Korczyńska-Partyka Dobrosława (2018), Urbanonatura - hybrydyczna przestrzeń miasta. Na przykładzie twórczości Mirona Białoszewskiego, „Teksty Drugie”, nr 2, s. 138-155.

Lefebvre Henri (2004), Rhythmanalysis. Space, Time and Everyday Life, trans. S. Elden, G. Moore, introd. S. Elden, London-New York: Continuum.

Mayol Pierre (2011), Mieszkać, w: M. de Certeau, L. Giard, P. Mayol, Wynaleźć codzienność 2. Mieszkać, gotować, przeł. K. Thiel-Jańczuk, Kraków: Wydawnictwo Uniwersytetu Jagiellońskiego, s. 3-136.

Rembowska-Płuciennik Magdalena (2007), W cudzej skórze. Fokalizacja zmysłowa a literackie reprezentacje doświadczeń sensualnych, w: Literackie reprezentacje doświadczenia, red. W. Bolecki, E. Nawrocka, Warszawa: Instytut Badań Literackich PAN, s. $51-67$.

Rewers Ewa (2005), Post-polis. Wstęp do filozofii ponowoczesnego miasta, Kraków: Universitas.

Stronciwilk Agata (2016), Parergon. O granicach, ograniczeniach i tożsamości obrazu w twórczości Kamila Kuskowskiego, w: Pomiędzy tożsamością a obrazem, red. M. Markiewicz, A. Stronciwilk, P. Ziegler, Katowice: grupakulturalna.pl, Uniwersytet Śląski, s. 199-216. 


\title{
Miron Białoszewski as the Urban Rhythmanalytic: On Function of the Gaze in Chamowo
}

\begin{abstract}
The article analyzes Chamowo, a journal by Miron Białoszewski, in which the writer recounts his experience of the block housing estate in Lizbonska street in Warsaw. The leitmotive in the text is the function of the gaze as Białoszewski devotes special attention to the action of looking through the window of his new flat. By concentrating on this apparently prosaic activity, the author of the article reflects upon the ways in which a city can be perceived and lived in. She also analyses the ways of narrating the urban space and representing the everyday of block housing estates, to include finally the rhythmanalysis of the urban space.
\end{abstract}

Keywords: urban studies, literary representations of city, visual turn, block housing estate, rhythmanalysis 